\title{
AN EMPIRICAL ASSESSMENT OF PERSONAL SELLING AS A MARKETING STRATEGY IN INDIAN INSURANCE SECTOR: A CASE OF PRIVATE INSURERS IN DELHI AND NCR REGION
}

\author{
Sameer Shekhar \\ Post-Doctoral Fellow, Indian Institute of Foreign Trade (IIFT), New Delhi, India \\ N. Jena \\ Head, EXIM \& Logistics, Jindal Stainless Limited, New Delhi, India
}

\begin{abstract}
The role of promotion is quite significant in a developing country with low literacy rate and pre-dominance of rural economy, and India is one of the best examples to have strong promotional measures to persuade customers for the kind of products and services for which they have greater need, but they lack in having proper information and understanding about the product. Insurance is one such service offering which is largely in demand by Indian population of all regions, be it rural population or urban population. The life insurance products success in business depends heavily on effective promotional measure, especially the personal selling plays vital role in converting prospects into buyer as it directly connects the sellers and buyers. The study tries to examine the effectiveness of different objectives of personal selling based on the data collected from officials of select insurance providing private companies product including that of HDFC, ICICI, Bajaj Allianz, Max Life, and Tata AIA in Delhi. To reach the inferences, factor analysis has been used reflecting that the private insurers are having three major objectives to use personal selling as means of effective marketing strategy.
\end{abstract}

Key words: Insurance, Personal Selling, Private Insurer, Factor Analysis, Promotion Cite this Article: Sameer Shekhar and N. Jena, An Empirical Assessment of Personal Selling as a Marketing Strategy in Indian Insurance Sector: A Case of Private Insurers in Delhi and NCR Region, International Journal of Management, 11(12), 2020, pp 2983-2993.

http://iaeme.com/Home/issue/IJM?Volume=11\&Issue=12 
An Empirical Assessment of Personal Selling as a Marketing Strategy in Indian Insurance Sector: A Case of Private Insurers in Delhi and NCR Region

\section{INTRODUCTION}

In the age of cutthroat competition, mode of personal selling is preferred by the business organisation which have many competitors so that the potential customers in specific geographical region can be directly contacted. Generally, the mode of promotion is adopted for the specific customer base where other mode of communication and advertisement cannot reach effectively and thus promotion of the firm's product or service become quite difficult. Personal selling deals existing customers of prosects on personal basis satisfying them with their doubts and queries winning their trust and bring their mindset in the ambit of confidence to take purchasing decision (Evans and Berman, 2007). American Marketing Association defines personal selling as a form of oral presentation and a conversation with one or more prospective purchaser for the purpose of making sales. The definition explores four basic qualities of personal selling efforts such as a promotion tool used in any company i.e., personal contact with prospects; growing relationship with prospects; immediate communication adjustments and the immediate feedback and responses from prospects (Agarwal, 2007). Knox (2006) assumes it to have the power to influence people to our sell for which they may not have thought of buying until we called their attention to it. The seller discovers the prospects and stimulates their needs through personal selling. Particularly, in life insurance product promotion and maximisation of sales volume, personal selling plays crucial role. It is highly personalised service that seeks to cater prospects not just with the insurance cover but with proper information and educating them about whole procedure to claim cover under different circumstances (Palande et al., 2004).

After the development, proper pricing, and determination of channel delivery communication and information about the policy traits with target prospects becomes essential as a part of marketing strategy which is communicated through many mass media such as advertising, sales promotion, public relations or through personal mediums such as personal selling and direct marketing. Insurance policies are mostly the subject of promotion adopting personal selling with certain objectives defined by the insurance company based on the nature of the policy.

Table 1 Objectives of Personal Selling

\begin{tabular}{|c|c|}
\hline Short Term Objectives & Long Term Objectives \\
\hline $\begin{array}{l}\text { - To assist customers in choosing right } \\
\text { policies, } \\
\text { - To providing information to prospects, } \\
\text { - To maximise sales volume, to collect } \\
\text { management, } \\
\text { - To keep selling expenses limited to set } \\
\text { budget, } \\
\text { - To minimise market competition, and } \\
\text { To contribute to profitability within a } \\
\text { specified period of time. }\end{array}$ & $\begin{array}{l}\text { To perform whole selling functions; to serve } \\
\text { customers, } \\
\text { To build long relationship with customers personally } \\
\text { and directly, } \\
\text { To keep clients informed about the changes in product } \\
\text { and other aspects over different periods of time, and } \\
\text { To satisfy customer over long run to secure and } \\
\text { maintain customers' cooperation in promoting product } \\
\text { and services, } \\
\text { To provide advice and assistance to customers in } \\
\text { choosing right product and services etc. }\end{array}$ \\
\hline
\end{tabular}

The prominence of personal selling as a tool for promotion of insurance products keeping in view the different objectives provides space for their effectiveness assessment. Major objectives are thus identified based on literature survey and their effectiveness have been measured using perception of the officials. 


\section{LITERATURE REVIEW}

The act of personal selling has been in practice since old age which can be linked with the age when there existed barter system (Osuagwu, 2002), and thus is considered as one of the oldest professions (Kotler and Keller, 2009). It is being considered one of the most effective mechanism of promotion in today's world as well. It can persuade the customers and prospects as it stands by personal presentation and providing enough space to the customers and market to interact, enquire, understand, and decide about the product of services a firm is willing to sell. The personal presentation by salesperson or sales force is significant determinant as recognised by in making a sale or customer relationship building (Kotler and Armstrong, 2006). It is also defined as oral presentation intending conversation with buyers for making sales (Achumba, 2000). It is an integrated process, incorporating the objective of discovering needs of the potential buyers, sharing information about the suitable products, informing about the traits and offers along with the benefits of the product or service, and developing long term relationship with customers adding value to the offerings (Manning and Reece, 2007). It is the direct method of selling (Jobber and Lancaster, 2009) by a person on behalf of the business firm who describes all products and services in face-to-face mode (Zeithaml et al., 2010).

A firm looks to maximise market share, expand the customer base, and win the trust of the customers by communicating benefits and characteristics, in lieu of which different promotional measures such as advertising, sales promotion, public relation etc. (Olson \& Peter, 2010) are adopted but among all personal selling mechanism is believed to be more effective in meeting all these objectives. It is not confined to only physical interface of salesperson and the customer, but now a days is involving interpersonal communication through virtual interface including telephone, email, video, or web conference as well.

Several studies have been conducted by the firms and academicians investigating the significance of personal selling as a company's promotional measure. A company looks to focus on personal selling measure with the view of converting prospects into buyer and capturing market share by injecting confidence and winning trust of the customers. The variables which are acting as major objectives of personal selling from firm point of view have been listed and described in Table 2.

Table 2 Select Benefits of Personal Selling from Marketing Strategy Perspective as Considered by Different Researchers

\begin{tabular}{|c|c|c|c|}
\hline S.N. & Variables & Authors (Year) & Description \\
\hline 1 & $\begin{array}{l}\text { Information to } \\
\text { Potential Customers }\end{array}$ & $\begin{array}{l}\text { Szymanski, (1988); Wotruba, } \\
\text { (1991); Anderson, (1996); Bass, } \\
\text { (1997); Dwyer and Martin, (2000); } \\
\text { Smith et al., (2004); Andzullis et } \\
\text { al., (2012); }\end{array}$ & $\begin{array}{l}\text { Personal selling is persuasive and conveys } \\
\text { product characteristics, service agreements, } \\
\text { prices, deals, and offers to the potential } \\
\text { customers. }\end{array}$ \\
\hline 2 & $\begin{array}{l}\text { Winning buyers' } \\
\text { confidence }\end{array}$ & $\begin{array}{l}\text { Jolson, (1997); Dwyer et. Al., } \\
\text { (2000); Anderson and Huang, } \\
(2006) \text {; Murithi, (2015); Yousif, } \\
(2016) \text {; Lee, }(2017)\end{array}$ & $\begin{array}{l}\text { By solving a customer's doubts and queries a } \\
\text { personal seller can win buyer's confidence on } \\
\text { behalf of the firm. }\end{array}$ \\
\hline 3 & $\begin{array}{l}\text { Facilitating direct } \\
\text { mutual } \\
\text { communication }\end{array}$ & $\begin{array}{l}\text { Wotruba, T. R. (1991); Weitz and } \\
\text { Bradford, (1999); Fam and } \\
\text { Merrilees, (1998); Dwyer et al., } \\
\text { (2000); Jacobs et al., (2001); Elrod } \\
\text { and Fortenberry, (2020) }\end{array}$ & $\begin{array}{l}\text { Personal selling provides ample space for two- } \\
\text { way communication and is more capable of } \\
\text { answering the customer's doubts and queries. }\end{array}$ \\
\hline 4 & $\begin{array}{l}\text { Capture market } \\
\text { shares }\end{array}$ & $\begin{array}{l}\text { Caywood and Laczniak, (1986); } \\
\text { Jolson, (1997); Rowley, (1998); } \\
\text { Sharma, and Gassenheimer, } \\
\text { (2009); Kurata, (2019) }\end{array}$ & $\begin{array}{l}\text { Personal selling helps to gauge the market } \\
\text { demography, taste, trend and expectation, } \\
\text { consequently offering the bundle of offerings } \\
\text { which attract more prospects. }\end{array}$ \\
\hline
\end{tabular}


An Empirical Assessment of Personal Selling as a Marketing Strategy in Indian Insurance Sector: A Case of Private Insurers in Delhi and NCR Region

\begin{tabular}{|c|c|c|c|}
\hline 5 & $\begin{array}{l}\text { Building personal } \\
\text { relationship with } \\
\text { client }\end{array}$ & $\begin{array}{l}\text { Doyle and Roth, (1992); Jolson, } \\
\text { (1997); Macintosh et al., (1999); } \\
\text { Crittenden et al., (2014); Adesoga, } \\
\text { (2016) }\end{array}$ & $\begin{array}{l}\text { Personal selling helps in developing value } \\
\text { customers and developing long term } \\
\text { relationship leading to rate of retention. }\end{array}$ \\
\hline 6 & $\begin{array}{l}\text { Information to } \\
\text { management about } \\
\text { market }\end{array}$ & $\begin{array}{l}\text { Wotruba, (1991); Bass, (1997); } \\
\text { Weitz and Bradford, (1999); } \\
\text { McClaren, (2000); Cross et al., } \\
\text { (2001); Jones et al., (2005); } \\
\text { Moncrief and Marshall, (2005) }\end{array}$ & $\begin{array}{l}\text { Personal selling helps management in PEST } \\
\text { analysis of the market and in taking more } \\
\text { accurate and rational decisions regarding } \\
\text { product and sales. }\end{array}$ \\
\hline 7 & $\begin{array}{l}\text { Maximise sales } \\
\text { volume }\end{array}$ & $\begin{array}{l}\text { Ramaseshan, (1990); Shipley and } \\
\text { Jobber, (1994); Geiger et al., } \\
\text { (2009); Pettigrew et al., (2015); }\end{array}$ & $\begin{array}{l}\text { By providing accurate information, } \\
\text { competence in solution of customer's doubt } \\
\text { and queries a personal seller wins the buyer's } \\
\text { and potential buyer's confidence leading to } \\
\text { expansion of market and sales volumes } \\
\text { therefore. }\end{array}$ \\
\hline 8 & $\begin{array}{l}\text { Assist prospects in } \\
\text { choosing suitable } \\
\text { product }\end{array}$ & $\begin{array}{l}\text { D'agostino, (1993); Anderson, } \\
\text { (1996); Swan et al., (1999); Aura, } \\
\text { (2010); Mamo, (2013); Elrod, and } \\
\text { Fortenberry, (2020) }\end{array}$ & $\begin{array}{l}\text { A personal seller knowing the customers more } \\
\text { closely is more capable in providing } \\
\text { suggestions on the most suitable product to the } \\
\text { specific buyer based on income, need and } \\
\text { other factors affecting purchasing decision. }\end{array}$ \\
\hline 9 & $\begin{array}{l}\text { Minimising } \\
\text { competition by other } \\
\text { competitoes }\end{array}$ & $\begin{array}{l}\text { Meidan, (1980); Flaherty, (1999); } \\
\text { Leigh and Marshall, (2001); Pollay, } \\
\text { (2007); He et al., (2013) }\end{array}$ & $\begin{array}{l}\text { Salesperson is more capable in developing } \\
\text { high rapport with the customers by allowing } \\
\text { them to negotiation, providing friendly advices } \\
\text { and flexibility sometimes leads to expansion in } \\
\text { customer base as well as reliance on the brand } \\
\text { and product. }\end{array}$ \\
\hline 10 & $\begin{array}{l}\text { Accurate information } \\
\text { about policy product }\end{array}$ & $\begin{array}{l}\text { Brooksbank, (1995); Widmier et al. } \\
\text { (2002); Ferrell et al., (2007); Wang } \\
\text { et al., (2012) }\end{array}$ & $\begin{array}{l}\text { A personal seller provides more accurate } \\
\text { information about the policy leading to easy } \\
\text { understanding to customers and makes it an } \\
\text { effective tool of promotion. }\end{array}$ \\
\hline
\end{tabular}

Total 10 variables were identified based on literature survey as have been presented in Table 2. These variables consist of Information to potential customers (VR1), Winning buyers' confidence (VR2), Facilitating direct mutual communication (VR3), Capture market shares (VR4), Building personal relationship with client (VR5), Information to management about market (VR6), Maximise sales volume (VR7), Assist prospects in choosing suitable policies (VR8), Minimising competition by other competitors (VR9), and Accurate information about policy product (VR10).

Keeping these variables in consideration as helping the private companies indulged in personal selling of insurance policy product, a null hypothesis has been considered for testing i.e., 'There is not any significant relationship among the variables of present database.'

\section{METHODOLOGY}

It is an empirical study based on first-hand information in which an attempt has been made to assess the personal selling objectives of select private insurance companies. In this perspective, the views of officials of HDFC, ICICI prudential, Tata AIA, Max Life, and Bajaj Allianz have been considered, in the region of Delhi have been taken through a survey with the help of structured questionnaire. The data was collected on five-point Likert scale which have been further analysed using parametric test i.e., factor analysis. 


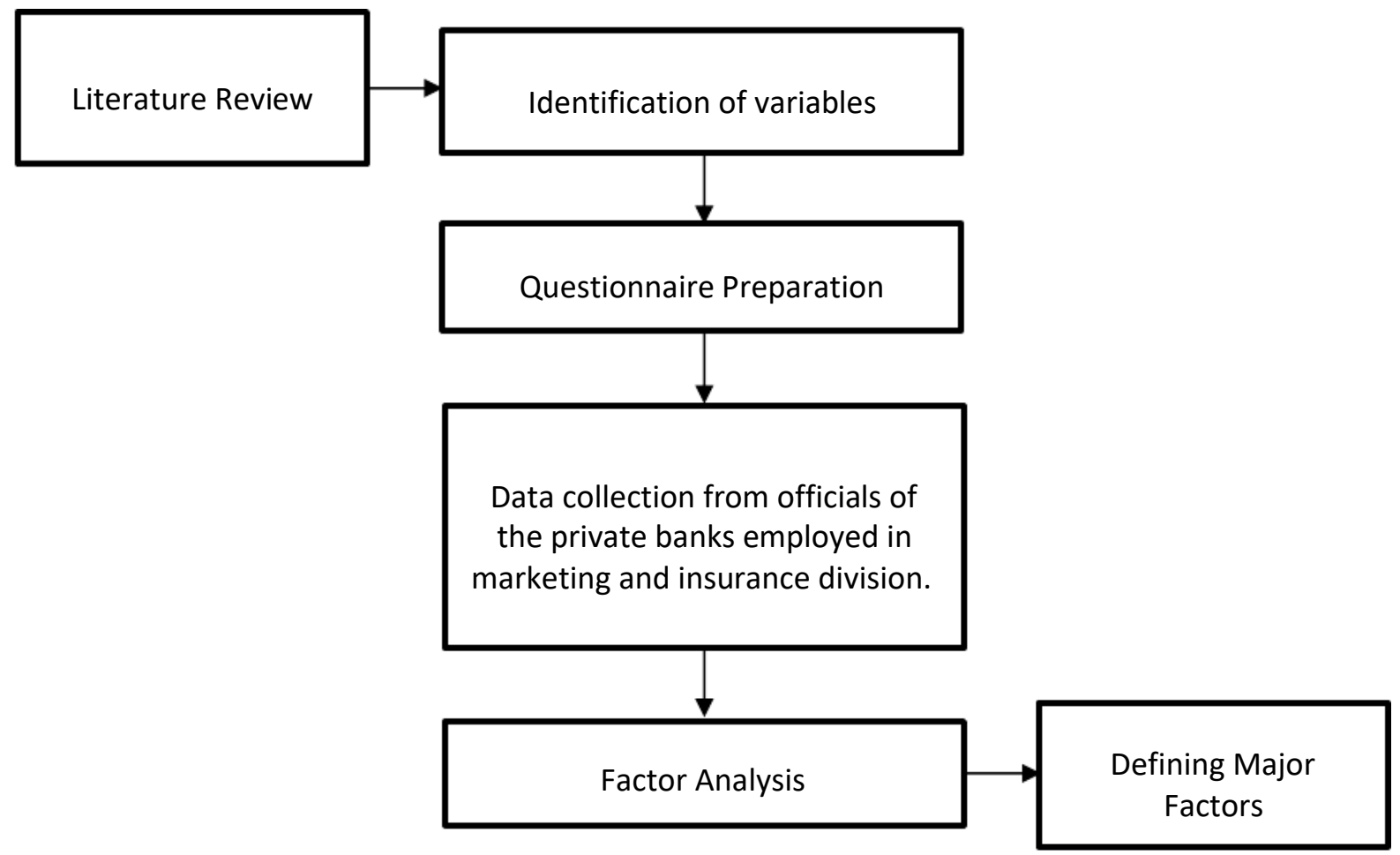

Figure 1 Flow Diagram of Methodology Framework

For the purpose, Cronbach's alpha test has been conducted to check the overall reliability of present dataset. Further, factor analysis technique has been employed to extract the valuable information.

\section{ANALYSIS AND DISCUSSION}

The set of factor analysis consists of KMO \& Bartlett's test, communalities, Principal Component Analysis, and naming of resulted factors with considered variables. Table 3 presents the reliability statistics. There are various reliability coefficients. Out of them Cronbach's alpha is most commonly used to check the reliability of data base. Cronbach's alpha reliability coefficient normally ranges between 0 and 1 . However, there is no lower limit to the coefficient. The nearer Cronbach's alpha coefficient is to 1.0 the greater the internal consistency of the items in the scale.

Table 3 Reliability Statistics

\begin{tabular}{|c|c|}
\hline Cronbach's Alpha & N of Items \\
\hline .681 & 10 \\
\hline
\end{tabular}

Table 4 KMO and Bartlett's Test

\begin{tabular}{|l|l|l|}
\hline \multicolumn{2}{|l|}{ Kaiser-Meyer-Olkin Measure of Sampling Adequacy } & .745 \\
\hline \multirow{3}{*}{ Bartlett's Test of Sphericity } & Approx. Chi-Square & 197.074 \\
\cline { 2 - 3 } & Df & 43 \\
\cline { 2 - 3 } & Sig. & .000 \\
\hline
\end{tabular}

The calculated Cronbach's alpha value for the overall scale is equal to .681 which is reflects that the current data set is reliable for further analysis purpose. As the study has defined factor analysis to conduct analysis, KMO Bartlett's Test has been run to get the conclusive evidence regarding validity of CFA on the set data considered. Table 4 reveals that the Kaiser-Meyer- 
An Empirical Assessment of Personal Selling as a Marketing Strategy in Indian Insurance Sector: A Case of Private Insurers in Delhi and NCR Region

Oklin measure of sampling adequacy is an index to examine the appropriateness of factor analysis. In the analysis, a high value .745 points that factor analysis is appropriate and the value below 0.5 specifies that factor analysis may not be appropriate. Consequently, our calculated KMO value (.745) indicates that factor analysis is appropriate for the present database. Moreover, Bartlett's Test of Sphericity checks the overall implication of correlation matrix to examine the null hypothesis which states that 'there is no significant relationship between the variables of present database'. The test reveals that the p-value is .000 , which is less than the alpha value of 0.05 at 95 percent confidence level. Thus, the null hypothesis has been rejected reflecting that the variables are correlated. The calculation confirms that factor analysis may be applied to analyse the data base.

Further, Table 5 shows the communalities of variables of dataset showing the proportion of common variance within a variable. Principal component analysis based on the initial assumption reflect that communalities of all variances are 1 before extraction. Communalities after extraction indicate the degree to which the variance of the variables are explained. High communality indicates that the extracted components represent the variables well. For instance, in case of V1, it can be stated that 55.3 percent of the variance associated with V1 is common. The variances in the variables have been shown in communalities table (Table 5).

Table 5 Communalities of the Variables

\begin{tabular}{|c|l|c|c|}
\hline \multicolumn{2}{|c|}{ Variables } & Initial & Extraction \\
\hline VR1 & Information to potential customers & 1.000 & .553 \\
\hline VR2 & Winning buyers' confidence & 1.000 & .634 \\
\hline VR3 & Facilitating direct mutual communication & 1.000 & .697 \\
\hline VR4 & capture market shares & 1.000 & .747 \\
\hline VR5 & Building personal relationship with client & 1.000 & .769 \\
\hline VR6 & Information to management about market & 1.000 & .318 \\
\hline VR7 & Maximise sales volume & 1.000 & .749 \\
\hline VR8 & Assist prospects in choosing suitable policies & 1.000 & .681 \\
\hline VR9 & Minimising competition by other insurers & 1.000 & .633 \\
\hline VR10 & Accurate information about policy product & 1.000 & .623 \\
\hline
\end{tabular}

Extraction Method: Principal Component Analysis.

On the basis of principle component analysis, the variance is explained by the initial solution, the extracted components, and the rotated components, and likely the results are revealed in Table 6 . The first section of the table shows the variances explained by the initial solution, which discloses that there are ten possible factors. In order to choose the effective factors, the factors with given values of more than 1 are requested for extracted solution. The second section of the table shows the variance explained by the extracted factors before rotation. The cumulative variability explained by these factors in the extracted solution is 68.238 which are similar to the initial solution and accordingly, it has been noted that no initial solution is lost due to hidden factors. The third and last section of the table presents variance explained by the extracted factors after rotation and the relative importance of the three factor is equalized. The rotated factor model makes some small adjustments to all the three extracted factors. It has been observed from the result that three main objectives are considered significant in the formulation and implementation of personal selling policies in the considered private insurance companies. 
Table 6 Total Variance Explained

\begin{tabular}{|c|c|c|c|c|c|c|c|c|c|}
\hline \multirow{2}{*}{ Component } & \multicolumn{3}{|c|}{ Initial Eigenvalues } & \multicolumn{3}{c|}{$\begin{array}{c}\text { Extraction Sums of Squared } \\
\text { Loading }\end{array}$} & \multicolumn{2}{|c|}{$\begin{array}{c}\text { Rotation Sums of Squared } \\
\text { Loadings }\end{array}$} \\
\cline { 2 - 11 } & Total & $\begin{array}{c}\text { \% of } \\
\text { Varianc } \\
\mathbf{e}\end{array}$ & $\begin{array}{c}\text { Cumulative } \\
\text { \% }\end{array}$ & Total & $\begin{array}{c}\text { \% of } \\
\text { Variance }\end{array}$ & $\begin{array}{c}\text { Cumulative } \\
\%\end{array}$ & Total & $\begin{array}{c}\text { \% of } \\
\text { Variance }\end{array}$ & $\begin{array}{c}\text { Cumulative } \\
\%\end{array}$ \\
\hline VR1 & 3.938 & 39.386 & 39.386 & 3.938 & 39.386 & 39.386 & 3.035 & 30.354 & 30.354 \\
\hline VR2 & 1.660 & 16.601 & 55.987 & 1.660 & 16.601 & 55.987 & 2.038 & 20.371 & 50.725 \\
\hline VR3 & 1.225 & 12.251 & 68.238 & 1.225 & 12.251 & 68.238 & 1.751 & 17.513 & 68.238 \\
\hline VR4 & .930 & 7.301 & 75.539 & & & & & & \\
\hline VR5 & .740 & 6.504 & 82.043 & & & & & & \\
\hline VR6 & .599 & 4.889 & 86.932 & & & & & & \\
\hline VR7 & .534 & 5.245 & 92.177 & & & & & & \\
\hline VR8 & .303 & 3.233 & 95.41 & & & & & & \\
\hline VR9 & .242 & 2.428 & 97.838 & & & & & & \\
\hline VR10 & .226 & 2.162 & 100 & & & & & & \\
\hline
\end{tabular}

Extraction Method: Principal Component Analysis.

In order to obtain the variables of each factor, rotated component matrix has been constructed with the help of Principal Component Analysis and Varimax Rotation Method. The result has been shown in the Table 7. The criterion for selecting variable under each factor is equal to 0.5 or more than 0.5 and has been found that all the ten variables are significant as per the response analysis.

Table 7 Rotated Component Matrix

\begin{tabular}{|c|c|c|c|}
\hline Variables & \multicolumn{3}{|c|}{ Component } \\
\hline & $\mathbf{1}$ & $\mathbf{2}$ & $\mathbf{3}$ \\
\hline VR1 & .343 & .328 & .577 \\
\hline VR2 & -.076 & .137 & .783 \\
\hline VR3 & .531 & .461 & .458 \\
\hline VR4 & .087 & .819 & -.251 \\
\hline VR5 & .881 & -.019 & .112 \\
\hline VR6 & .525 & .214 & -.115 \\
\hline VR7 & .864 & -.114 & .022 \\
\hline VR8 & .756 & .255 & .230 \\
\hline VR9 & .013 & .763 & .201 \\
\hline VR10 & .535 & .463 & .345 \\
\hline
\end{tabular}

Extraction Method: Principal Component Analysis.

Rotation Method: Varimax with Kaiser Normalization.

a. Rotation converged in 4 iterations.

Table 8 Objectives of Personal Selling Strategy in LIC of India

\begin{tabular}{|l|c|l|c|}
\hline \multicolumn{1}{|c|}{ Main Factor } & Item & \multicolumn{1}{|c|}{ Sub Factor } & Factor Load \\
\hline \multirow{4}{*}{$\begin{array}{l}\text { Promotion and } \\
\text { Selling Perspective }\end{array}$} & VR3 & Facilitating direct mutual communication & .531 \\
\cline { 2 - 4 } & VR5 & Building personal relationship with client & .881 \\
\cline { 2 - 4 } & VR6 & Information to management about market & .525 \\
\cline { 2 - 4 } & VR7 & Maximise sales volume & .864 \\
\cline { 2 - 4 } & VR8 & Assist prospects in choosing suitable policies & .756 \\
\cline { 2 - 4 } & VR10 & Accurate information about policy product & .535 \\
\hline \multirow{2}{*}{$\begin{array}{l}\text { Competitive } \\
\text { Approach }\end{array}$} & VR4 & Capture market shares & .819 \\
\cline { 2 - 4 } $\begin{array}{l}\text { Customer } \\
\text { Orientation }\end{array}$ & VR9 & Minimising competition by other insurers & .577 \\
\cline { 2 - 4 } & VR1 & Information to potential customers & .783 \\
\hline
\end{tabular}


An Empirical Assessment of Personal Selling as a Marketing Strategy in Indian Insurance Sector: A Case of Private Insurers in Delhi and NCR Region

Table 8 summarises that VR3 (.531), VR5 (.881), VR6 (.525), VR7 (.864), VR8 (.756) and VR10 (.535) are the six variables which are effective from promotion and selling point of view; VR4 (.819) and VR9 (.763) are important and effective from the perspective of competitive approach; and VR1 (.577) and VR2 (.783) are significant from customer orientation point of view.

\section{CONCLUSION}

Based on the results of the facto analysis all the variables have been categorised into the three major factors i.e., Promotion and Selling Perspective, Competitive Approach, and Customer Orientation which may be considered while drafting and implementing personal selling strategy by the private insurers viz. HDFC bank, ICICI Prudential, Bajaj Allianz, Tata AIA, and Max Life Insurance in Delhi region and in the region of NCR. The result clearly shows that the private insurance companies have adopted personal selling strategy with an objective of promotion and increase in the selling of the policy products and expanding sales involving facilitating direct mutual communication, building personal relationship with client, providing market information to management, maximise sales volume, assist prospects in choosing suitable policies, and accurate information about policy product. Competitive approach including market shares capture, and minimising competition are the blends has been found as second most important factor in considering personal selling. The third most significant objective of personal selling has emerged from customers' viewpoint i.e., customer orientation encompassing providing information to prospects, and winning buyers' confidence, as both the variables lead to bring potential customer and existing customer in state of psychology where he/she is able to take purchasing decision and is confident over the policy product that leads to retention.

\section{REFERENCES}

[1] Adesoga, A. (2016). Examination of the relevance of personal selling in marketing activities: A descriptive method. Journal of accounting and management, 6(2), 103-116.

[2] Agarwal, R. C. (2007). Salesmanship and Advertising. Lakshmi Narain Agarwal Educational Publishers, Agra, p.269

[3] Anderson, R. E. (1996). Personal selling and sales management in the new millennium. Journal of Personal Selling \& Sales Management, 16(4), 17-32.

[4] Anderson, R. E., \& Huang, W. Y. (2006). Empowering salespeople: Personal, managerial, and organizational perspectives. Psychology \& Marketing, 23(2), 139-159.

[5] Andzulis, J. M., Panagopoulos, N. G., \& Rapp, A. (2012). A review of social media and implications for the sales process. Journal of Personal Selling \& Sales Management, 32(3), 305316.

[6] Aura, J. (2010). Salesperson's customer orientation in the personal selling process and in the use of personal selling techniques in the business-to-business setting. Lappeenranta University of Technology

[7] Bass, B. M. (1997). Personal selling and transactional/transformational leadership. Journal of Personal Selling \& Sales Management, 17(3), 19-28.

[8] Brooksbank, R. (1995). Selling and sales management in action: The new model of personal selling: micromarketing. Journal of Personal Selling \& Sales Management, 15(2), 61-66.

[9] Caywood, C. L., \& Laczniak, G. R. (1986). Ethics and personal selling: Death of a salesman as an ethical primer. Journal of Personal Selling \& Sales Management, 6(2), 81-88. 
[10] Crittenden, V. L., Crittenden, W. F., \& Crittenden, A. B. (2014). Relationship building in the financial services marketplace: The importance of personal selling. Journal of Financial Services Marketing, 19(2), 74-84.

[11] Cross, J., Hartley, S. W., Rudelius, W., \& Vassey, M. J. (2001). Sales force activities and marketing strategies in industrial firms: Relationships and implications. Journal of Personal Selling \& Sales Management, 21(3), 199-206.

[12] D'agostino, R. J. (1993). U.S. Patent No. 5,231,571. Washington, DC: U.S. Patent and Trademark Office.

[13] Doyle, S. X., \& Roth, G. T. (1992). Selling and sales management in action: The use of insight coaching to improve relationship selling. Journal of Personal Selling \& Sales Management, 12(1), 59-64.

[14] Dwyer, S., Hill, J., \& Martin, W. (2000). An empirical investigation of critical success factors in the personal selling process for homogenous goods. Journal of Personal Selling \& Sales Management, 20(3), 151-159.

[15] Dwyer, S., Hill, J., \& Martin, W. (2000). An empirical investigation of critical success factors in the personal selling process for homogenous goods. Journal of Personal Selling \& Sales Management, 20(3), 151-159.

[16] Dwyer, S., Hill, J., \& Martin, W. (2000). An empirical investigation of critical success factors in the personal selling process for homogenous goods. Journal of Personal Selling \& Sales Management, 20(3), 151-159.

[17] Elrod, J. K., \& Fortenberry, J. L. (2020). Personal selling in health and medicine: using sales agents to engage audiences. BMC Health Services Research, 20(1), 1-6.

[18] Elrod, J. K., \& Fortenberry, J. L. (2020). Personal selling in health and medicine: using sales agents to engage audiences. BMC Health Services Research, 20(1), 1-6.

[19] Evans, R., Joel. and Berman Barry. (2007). Marketing Management; Cengage Learning India Private Limited, New Delhi, pp. 503-505.

[20] Fam, K. S., \& Merrilees, B. (1998). Cultural values and personal selling. International Marketing Review. 15(4), 246-256.

[21] Ferrell, O. C., Johnston, M. W., \& Ferrell, L. (2007). A framework for personal selling and sales management ethical decision making. Journal of Personal Selling \& Sales Management, 27(4), 291-299.

[22] Flaherty, T. B., Dahlstrom, R., \& Skinner, S. J. (1999). Organizational values and role stress as determinants of customer-oriented selling performance. Journal of Personal Selling \& Sales Management, 19(2), 1-18.

[23] Geiger, S., Guenzi, P., \& Paparoidamis, N. G. (2009). An empirical investigation into the impact of relationship selling and LMX on salespeople's behaviours and sales effectiveness. European Journal of Marketing.

[24] He, Z., Wang, S., \& Cheng, T. C. E. (2013). Competition and evolution in multi-product supply chains: An agent-based retailer model. International Journal of Production Economics, 146(1), 325-336.

[25] Jacobs, R. S., Hyman, M. R., \& McQuitty, S. (2001). Exchange-specific self-disclosure, social self-disclosure, and personal selling. Journal of Marketing Theory and Practice, 9(1), 48-62.

[26] Jolson, M. A. (1997). Broadening the scope of relationship selling. Journal of Personal Selling \& Sales Management, 17(4), 75-88.

[27] Jolson, M. A. (1997). Broadening the scope of relationship selling. Journal of Personal Selling \& Sales Management, 17(4), 75-88. 
An Empirical Assessment of Personal Selling as a Marketing Strategy in Indian Insurance Sector: A Case of Private Insurers in Delhi and NCR Region

[28] Jones, E., Brown, S. P., Zoltners, A. A., \& Weitz, B. A. (2005). The changing environment of selling and sales management. Journal of Personal Selling \& Sales Management, 25(2), 105111.

[29] Knox. J.M. (2006). The Science and Art of Selling. Cosimo, Inc, p-87

[30] Kurata, H. (2019). Is the information of customer types and preferences to personal selling worth the investment in innovative technology? A modeling approach. Journal of Retailing and Consumer Services, 49, 371-379.

[31] Lee, J. Y., Sridhar, S., \& Palmatier, R. W. (2017). The effect of firms' structural designs on advertising and personal selling returns. International Journal of Research in Marketing, 34(1), 173-193.

[32] Leigh, T. W., \& Marshall, G. W. (2001). Research priorities in sales strategy and performance. Journal of Personal Selling \& Sales Management, 21(2), 83-93.

[33] Macintosh, G., Anglin, K. A., Szymanski, D. M., \& Gentry, J. W. (1992). Relationship development in selling: a cognitive analysis. Journal of Personal Selling \& Sales Management, 12(4), 23-34.

[34] Mamo, S. (2013). An assessment of personal selling practice in NIB Insurance SC (Doctoral dissertation, St. Mary's University, Ethiopia).

[35] McClaren, N. (2000). Ethics in personal selling and sales management: A review of the literature focusing on empirical findings and conceptual foundations. Journal of Business Ethics, 27(3), 285-303.

[36] Meidan, A. (1980). Salesforce Management. Management Decision, 18(8), 418-453.

[37] Moncrief, W. C., \& Marshall, G. W. (2005). The evolution of the seven steps of selling. Industrial Marketing Management, 34(1), 13-22.

[38] Murithi, M. M. (2015). Effects of personal selling on sales: A case of women groups in Imenti North District, Meru County, Kenya.

[39] Pettigrew, S., Biagioni, N., Jones, S. C., Daube, M., Kirby, G., Stafford, J., \& Chikritzhs, T. (2015). Sales promotion strategies and youth drinking in Australia. Social Science \& Medicine, 141, 115-122.

[40] Pollay, R. W. (2007). More than meets the eye: on the importance of retail cigarette merchandising. Tobacco Control, 16(4), 270-274.

[41] Ramaseshan, B. (1990). Research note: Marketing budgeting practices of retailers. European Journal of Marketing, 24(8), 40-45.

[42] Rowley, J. (1998). Promotion and marketing communications in the information marketplace. Library review. 47(8), 383-387.

[43] Sharma, D., \& Gassenheimer, J. B. (2009). Internet channel and perceived cannibalization: Scale development and validation in a personal selling context. European Journal of Marketing, 43(7-8), 1076-1091.

[44] Shipley, D., \& Jobber, D. (1994). Size Effects on Sales Mangement Practices of Small Firms: A Study of Industrial Distributors. Journal of Personal Selling \& Sales Management, 14(1), 3143.

[45] Smith, T. M., Gopalakrishna, S., \& Smith, P. M. (2004). The complementary effect of trade shows on personal selling. International Journal of research in Marketing, 21(1), 61-76.

[46] Still, R. R., Cundiff, E. W., \& Govoni, N. A. (1976). Sales management: Decisions, policies, and cases. Prentice Hall of India, New Delhi, pp. 36-38 
[47] Swan, J. E., Bowers, M. R., \& Richardson, L. D. (1999). Customer trust in the salesperson: An integrative review and meta-analysis of the empirical literature. Journal of business research, 44(2), 93-107.

[48] Szymanski, D. M. (1988). Determinants of selling effectiveness: the importance of declarative knowledge to the personal selling concept. Journal of Marketing, 52(1), 64-77.

[49] Wang, E. S. T., Tsai, B. K., Chen, T. L., \& Chang, S. C. (2012). The influence of emotions displayed and personal selling on customer behaviour intention. The Service Industries Journal, 32(3), 353-366.

[50] Weitz, B. A., \& Bradford, K. D. (1999). Personal selling and sales management: A relationship marketing perspective. Journal of the academy of marketing science, 27(2), 241.

[51] Weitz, B. A., \& Bradford, K. D. (1999). Personal selling and sales management: A relationship marketing perspective. Journal of the academy of marketing science, 27(2), 241.

[52] Widmier, S. M., Jackson Jr, D. W., \& McCabe, D. B. (2002). Infusing technology into personal selling. Journal of Personal Selling \& Sales Management, 22(3), 189-198.

[53] Wotruba, T. R. (1991). The evolution of personal selling. Journal of Personal Selling \& Sales Management, 11(3), 1-12.

[54] Wotruba, T. R. (1991). The evolution of personal selling. Journal of Personal Selling \& Sales Management, 11(3), 1-12.

[55] Yousif, R. O. (2016). The Impact of Personal Selling on the Purchasing Behavior towards Clothes: A Case Study on the Youth Category. International Journal of Marketing Studies, 8(5), 128-135. 